NBER WORKING PAPER SERIES

\title{
RISK AND LACK OF DIVERSIFICATION UNDER EMPLOYEE OWNERSHIP AND SHARED CAPITALISM
}

\author{
Joseph R. Blasi \\ Douglas L. Kruse \\ Harry M. Markowitz \\ Working Paper 14229 \\ http://www.nber.org/papers/w14229
}

\author{
NATIONAL BUREAU OF ECONOMIC RESEARCH \\ 1050 Massachusetts Avenue \\ Cambridge, MA 02138 \\ August 2008
}

The original version of this paper was prepared for the Russell Sage/NBER conference in New York City, October 2006. This paper is part of the National Bureau of Economic Research's Shared Capitalism Research Project, funded by the Russell Sage and Rockefeller Foundations from 2001-2007. Additional funding for the General Social Survey questions was provided by the Beyster Institute of the University of California at San Diego, the ESOP Association, the Employee Ownership Foundation, Hewitt Associates, the National Center for Employee Ownership, the Profit Sharing Council of America, and American Capital Strategies. The authors wish to thank Tom Smith with the General Social Survey at the National Opinion Research Center of the University of Chicago and Peter Marsden of Harvard University with the National Organizations Study for their assistance in arranging the shared capitalism segment of both surveys. The authors wish to thank Daniel Kahneman of Princeton University for several generous discussions and communications with us about our ideas. The views expressed herein are those of the author(s) and do not necessarily reflect the views of the National Bureau of Economic Research.

NBER working papers are circulated for discussion and comment purposes. They have not been peerreviewed or been subject to the review by the NBER Board of Directors that accompanies official NBER publications.

(C) 2008 by Joseph R. Blasi, Douglas L. Kruse, and Harry M. Markowitz. All rights reserved. Short sections of text, not to exceed two paragraphs, may be quoted without explicit permission provided that full credit, including $\odot$ notice, is given to the source. 
Risk and Lack of Diversification under Employee Ownership and Shared Capitalism

Joseph R. Blasi, Douglas L. Kruse, and Harry M. Markowitz

NBER Working Paper No. 14229

August 2008

JEL No. D81,J33,J54,L23

\begin{abstract}
Some analysts view risk as the Achilles Heel of employee ownership and to some extent variable pay plans such as profit sharing and gainsharing. Workers in such "shared capitalist" firms may invest too much of their wealth in the firm, contrary to the principle of diversification. This paper addresses whether the risk in shared capitalism makes it unwise for most workers or whether the risk can be managed to limit much of the loss of utility from holding the extra risk. We create an index of financial security based on worker pay and wealth, and find that workers who feel financially insecure exhibit fewer of the positive outcomes associated with shared capitalism, and are less interested than other workers in receiving more employee ownership or even more profit sharing in their workplaces. This response is substantially lessened, however, when accounting for worker empowerment, good employee relations, and high-performance work bundles that appear to buffer worker response toward risk and increase interest in shared capitalism plans. We also discuss portfolio theory which suggests that any risky investment -- including stock in one's company -- can be part of an efficient portfolio as long as the overall portfolio is properly diversified. We show that given estimates of risk aversion parameters, workers could prudently hold reasonable proportions of their assets in employee stock ownership of their firm with only a modest loss in utility due to risk. A good strategy for firms is to personalize individual portfolios on the basis of worker characteristics and preferences, developing investment strategies that would diversify each worker's entire portfolio in ways consistent with individual risk preferences.
\end{abstract}

Joseph R. Blasi

Rutgers University

School of management and Labor Relations

Levin Building

New Brunswick, NJ 08544

and NBER

jrbru@hotmail.com

Douglas L. Kruse

School of Management and Labor Relations

Rutgers University

94 Rockafeller Road

Piscataway, NJ 08854

and NBER

dkruse@rci.rutgers.edu
Harry M. Markowitz

Rady School of Management

Otterson Hall, Room 4S1

9500 Gilman Dr. \#0553

La Jolla, CA 92093-0553

hmarkowitz@ucsd.edu 
"I am in favor of having as large a unit as market conditions will allow. . . To suppose that safety-first consists in having a small gamble in a large number of different [companies] where I have no information to reach a good judgment, as compared with a substantial stake in a company where one's information is adequate, strikes me as a travesty of investment policy."

John Maynard Keynes Letter to F.C. Scott on February 6, 1942 (1983) Note: Keynes managed the investments of a large British insurance company and the endowment funds of Kings College Cambridge (quoted in Bernstein 1992:48).

"The correlation among returns is not the same for all securities. We generally expect the returns on a security to be more correlated with those in the same industry than those of unrelated industries. Business connections among corporations, the fact that they service the same area, a common dependence on military expenditures, building activity, or the weather can increase the tendency of particular returns to move up and down together. To reduce risk it is necessary to avoid a portfolio whose securities are highly correlated with each other."

Harry M. Markowitz, Portfolio Selection (1991: 5)

A substantial proportion of private sector workers participate in some form of shared rewards and there is evidence that shared capitalism plays a positive role in economic performance (Kruse, Blasi, and Park, 2008; Freeman Kruse, and Blasi, 2008; Blasi et al., 2008; Harden, Kruse, and Blasi, 2008). With this level of incidence and these potential outcomes, it is incumbent on scholars to figure out whether and under what conditions such practices make sense or are really ill-advised. Since shared capitalism, especially in the form of employee stock ownership and stock options, is an investment, we need to examine it from the critical perspective of risk. This paper considers two questions: What is the impact of subjective risk on workers' attitudes, preferences, and behaviors under shared capitalism? Can employee ownership and other forms of worker equity participation be consistent with proper diversification? 
Many economists have seriously worried about the phenomenon of employee stock ownership because it possibly "put all one's eggs in one basket." Looking at subjective worker behavior, Benartzi and Thaler's incisive study (2001) found that workers put about $42 \%$ of their assets in the company stock account and then split the remaining assets fairly evenly between non-employee ownership equities and fixed income securities with the result that the workers in the companies with employee ownership are over $70 \%$ invested in equities, in effect, further adding to lack of diversification in their portfolios. Benartzi (2001) has shown that workers in large corporate defined contribution retirement plans (such as $401 \mathrm{k}$ plans) increase the proportion of their holdings in employee ownership of company stock after the company's equity performs well on the market, allocating four times more new investments to company stock in the future when the company stock had done well in the past. He concludes that this violates a cardinal law of economics, portfolio diversification. Meulbroek (2002) compares the risk of holding one company's stock to a diversified portfolio for all stocks listed in the Center For Research on Securities Prices (CRSP) and concludes “on average $42 \%$ of the stock's market value will be sacrificed by failing to diversify." (p. 29) She looked at expectations of what could happen rather than the specific tracking of actual data on employee investments in company stock and considered the extreme case of $100 \%$ employee investment in company stock. Meulbroek sees no rational basis for company stock ownership by employees whatsoever (2002: 14) and makes a strong recommendation against any employee ownership at all in the economy.

\section{Data and Methods}

We have done research on these questions using a unique dataset. The NBER Shared Capitalism Project uses a data set of 41,206 employee surveys that were conducted over the 
2001-2007 period in 14 companies and several hundred work sites worldwide with one or more shared capitalist programs. The companies were selected to vary in company size, industry, and type of shared reward program. The average response rate was $52.8 \%$. Within the NBER dataset $81.5 \%$ of the workers had one or more forms of shared capitalist rewards. The appendix describes the relevant variables used in our analysis. This dataset is particularly useful to examine risk because it provides a comprehensive description of the possible ways a worker can share in the profits or equity of the company plus detailed information on their income and wealth, organization of work, specific measures of their attitudes toward shared capitalism, their preferences for more or less shared capitalism, and their behavioral responses to shared capitalism (loyalty, turnover, and willingness to work harder for the company). These measures of worker attitudes, preferences, and behavioral responses are the main dependent variables of the study. Moreover, variables on empowerment and employee relations and work structure allow us to examine their role in the story. Analyses are conducted on only those workers with shared rewards, totalling 35,429 employees.

The economic insecurity score is the main independent variable of the study. The three components of a worker's economic insecurity score are the size of each worker's fixed annual pay, how many multiples each worker's total wealth (minus debt) is relative to that worker's fixed annual pay, and the extent to which each worker perceives they are competitively paid in the firm where they work. Briefly put, the score expresses how much cushion each worker's current capital offers them relative to their annual income, taking into account whether the worker feels fairly compensated or not based on expectations from the local labor market. If a worker perceives he or she is underpaid, then profit sharing or employee stock ownership may be perceived as wage substitution. The higher the score the more the worker's economic insecurity 
and the more the worker's capital is at risk. The construction of the economic insecurity score is explained in detail in the appendix.

Here is a concrete example of economic insecurity and economic security. At one extreme, that of the high economic insecurity score, is a worker with fixed annual pay of $\$ 25,000$, whose total wealth (minus debt) is less than $\$ 25,000$, and who perceives that she or he is being paid significantly below market for their job position relative to comparable workers. We hold that the more insecure worker -- just as Adam Smith predicts from his observations of the French sharecroppers in the Theoretical Perspectives section below -- will be resistant to risking his or her own capital in the firm. At the other extreme, that of the low economic insecurity score (i.e., high economic security), is a worker with fixed annual pay of $\$ 75,000$, whose total wealth is four multiples of annual pay at $\$ 300,000$, and who perceives that he or she is being paid significantly above the market rate. We hold that this worker will be more comfortable with shared capitalism. Table 1 shows the economic insecurity scores for the sample. There is a lot of variation in the sample. Because some components of the score were not contained in all company surveys, the score is only available for 22,980 workers.

Regarding methodology, the issue of unmeasured differences among the companies is directly addressed because regressions using the dataset include company fixed effects so that coefficients reflect within-company differences rather than cross company differences that might be due to unmeasured differences among the companies. Since the study lacks instruments to identify causality, there is no attempt to try to tease out possible causal links among the outcomes. Rather, these are tests for reduced form relationships between the economic insecurity score and changes in attitudes, preferences, and outcomes (behaviors), noting in the text whether the results may change when holding constant other variables (Bartholomew 1996; 
Bartholomew, Galbraith, Moustkaki, \& Steele 2002.) Since many of the dependent variables have three or four values with a natural ordering (e.g., "not at all true, not very true, somewhat true, and very true"), ordered probits are estimated that control for job and demographic characteristics. One advantage of the extensive NBER Shared Capitalism dataset is that we can control for many worker characteristics. The job characteristics controlled for are: occupation, education, tenure, hourly/salaried, hours worked, supervisory/non-supervisory, management level, and log of fixed pay (plus overtime). The demographic characteristics controlled for are: sex, age, marital status, family size, children, race, and disability.

\section{Theoretical Perspectives}

What we expect to find about the impact of risk on the attitudes, preferences and behavioral outcomes of workers in firms under shared capitalism has been inspired by the work of Adam Smith. A key theme of Smith's economics is that capitalism would result in better economic performance as a result of more effort, productivity, and wealth. Indeed, this is consistent with the literature on shared capitalism. Smith wrote about the evolution from feudalism to the new market system as part of a long line of economists who stressed that capitalism also involved greater risk and speculation. The principal advantage of feudalism for the worker was the protection it provided from such risk (see Book III, 2.2-2.21). Adam Smith however definitely recognized that a worker could be interested in shared rewards - as it were, full employee ownership and profit sharing -- but that it was not a common arrangement at that time. He wrote:

"It sometimes happens, indeed, that a single independent workman has stock sufficient both to purchase the materials of his work, and to maintain himself till it be completed. $\mathrm{He}$ is both master and workman, and enjoys the whole produce of his own labour, or the whole value which it adds to the materials upon which it is bestowed. It includes what are 
usually two distinct revenues, belonging to two distinct persons, the profits of stock, and the wages of labour." (Book I. 8.9-10)

Smith recognized the incentive value of such shared capitalist rewards and cited its role in improved economic performance. In writing about the French Metayers or sharecroppers as one example of a shared capitalist institution, he said:

"The proprietor furnished them with the seed, cattle, and instruments of husbandry, the whole stock, in short, necessary for cultivating the farm. The produce was divided equally between the proprietor and the farmer, after setting aside what was judged necessary for keeping up the stock, which was restored to the proprietor when the farmer either quitted, or was turned out of the farm. Land occupied by such tenants is properly cultivated at the expense of the proprietor as much as that occupied by slaves. There is, however, one very essential difference between them. Such tenants, being freemen, are capable of acquiring property, and having a certain proportion of the produce of the land, they have a plain interest that the whole produce should be as great as possible, in order that their own proportion may be so. A slave, on the contrary, who can acquire nothing but his maintenance, consults his own ease by making the land produce as little as possible over and above that maintenance."(Book III, chapter 2, 11-12) (as quoted in Laffont \& Martimort 2002:10)

However, Smith identified a critical problem with the idea in addressing risk under such shared capitalist arrangements when he identified the moral hazard problem of sharecropping: sharecroppers do not desire to risk their own capital. Thus he wrote:

"It could never, however, be the interest even of this last species of cultivators to lay out, in the further improvement of the land, any part of the little stock which they might save from their own share of the produce, because the lord, who laid out nothing, was to get one-half of whatever it produced.... It might be the interest of a metayer to make the land produce as much as could be brought out of it by means of the stock furnished by the proprietor; but it could never be his interest to mix any part of his own with it. In France, where five parts out of six of the whole kingdom are said to be still occupied by this species of cultivators, the proprietors complain that their metayers take every opportunity of employing the master's cattle rather in carriage than in cultivation; because in the one case they get the whole profits to themselves, in the other they share them with their landlord." (Book III, chapter 2, 13)(as quoted in Laffont \& Martimort 2002:10)

While he did not envision how such shared capitalist incentives would be structured in a complex economy, Smith clearly saw the advantages of shared capitalism. This analysis suggests that the incentive effect would be diminished if the worker's own capital was subject to 
excessive risk. We expect that workers will be risk averse in mixing their own capital with that of the firm.

While Smith's notion is based on salient historical observations, Daniel Kahneman and Amos Tversky's prospect theory $(1981,1986,1991)$ inspired us to develop a unique way to explore the issues at hand. Prospect theory holds that people decide about outcomes based on a reference point (reflecting their status quo) rather than based upon some "objective" final situation or status. In their view, this status quo "frames" their decision. They note that different attitudes towards risk will emerge when a person perceives gains relative to their reference point or losses relative to their reference point and that people will care more about potential losses than potential gains. The economic insecurity score provides one measure of a worker's status quo and is directly influenced by Adam Smith's observation that a worker will not want to risk his or her own capital in a shared capitalist arrangement.

\section{Hypotheses}

Reflecting Adam Smith's perspective that workers will not risk their own capital, this part of the paper explores subjective risk, namely, how workers in shared capitalist arrangements respond to variations in their economic insecurity. People are risk averse. Our first hypothesis is:

Hypothesis One: As the economic insecurity score increases, attitudes toward shared capitalism, preferences for variable pay, and workplace outcomes (behaviors) under shared capitalism will worsen.

Next we examine the impact of company culture. A worker's economic insecurity and response to shared capitalism are likely to be related to worker empowerment (influence over 
one's job and the workplace) and perceived fairness. In the absence of empowerment, shared capitalism may easily be seen as nothing more than increased income risk, whereas empowerment creates a greater sense that one can affect workplace performance and rewards under shared capitalism. Regarding fairness, a number of scholars have argued that economists should add to their analyses the "preferences that people have for being treated fairly" (Kahneman, Knetsch, and Thaler 1986a: S285-6; see also Akerlof 1979 and Arrow 1973). Good employee-management relations, where employees feel they are treated fairly, may be an important condition to create cooperation and higher performance under shared capitalism. Workers may therefore respond better to shared capitalism when they have greater empowerment and perceive better employee relations, diminishing the negative effects of economic insecurity. This is consistent with the idea that under the right conditions, shared capitalism can strengthen the "psychological contract" between employees and the firm (Rousseau and Shperling 2003). The second hypothesis is:

Hypothesis Two: Lack of empowerment and poor employee relations help explain the negative relationship between the economic insecurity score and attitudes toward shared capitalism, preferences for variable pay, and behavioral outcomes under shared rewards. Several researchers have linked a bundle of high performance work practices to either improved operating performance of individual facilities or better productivity, lower turnover, and better total shareholder return of firms (Appelbaum 2000; Becker and Huselid 2001; Cappelli and Neumark 2002; Ichniowski, Shaw, and Prennushi 1995). These bundles are characterized by a coordinated integration of the various "high performance people management" systems inside the firm and involve: selective recruitment, intensive training and performance management, self-directed work teams, employee involvement, and performance 
sharing. ${ }^{1}$ These bundles may interact with shared capitalism in the same way as hypothesized above for employee empowerment and employee relations: such practices can help create the means for employees to positively affect performance, and strengthen the psychological contract between employees and the firm. This is likely to make employees more receptive to shared capitalism, and diminish the negative effects of economic insecurity. Put simply, we hypothesize that a more engaging work system will buffer worker response to risk. The third hypothesis is:

Hypothesis Three: The presence or absence of a high performance work system helps explain the negative effect of high economic insecurity on attitudes toward shared capitalism, preferences for variable pay, and outcomes under shared rewards.

\section{Results}

Risk aversion is the general norm for workers. Using the employee surveys of the NBER Shared Capitalism dataset we can briefly review findings on the general preference for risk aversion or risk seeking among the workers in the sample based on demographic group and job characteristics. This is based on responses to the question:

Some people like to take risks and others dislike taking risks. Where would you place yourself on a scale of how much you like or dislike taking risks, where 0 is hating to take any kind of risk and 10 is loving to take risks?

Hate to take risks Love to take risks

$\begin{array}{lllllllllll}0 & 1 & 2 & 3 & 4 & 5 & 6 & 7 & 8 & 9 & 10\end{array}$

The sample tends toward risk-seeking: the mean is 5.6, with only one-quarter $(26 \%)$ giving an answer of 4 or below, while $55 \%$ gave an answer above 5 . Those with low earnings are predictably more likely to say they are risk averse, with 53\% giving scores of 5 or below, 
compared to $27 \%$ of the high earners. The results are similar when breaking the figures down by wealth categories.

Another measure of risk aversion comes from the survey question:

You are offered a bet. You have a $10 \%$ chance of winning $\$ 1000$. Would you take the bet if it cost you: (mark highest price you would pay)

$\square \$ 150 \quad \square \$ 100 \quad \square \$ 50 \quad \square \$ 20 \quad \square \$ 10 \quad \square \$ 1$

$\square$ Would not pay anything

One-third (33\%) of the individuals indicated extreme risk aversion, saying they would pay nothing or only $\$ 1$ for the bet, while at the other extreme, $7 \%$ would pay $\$ 100$ and $2 \%$ would pay $\$ 150$ (above the expected value of the bet, indicating extreme risk loving). This is also related to earnings: $41 \%$ of the low earners would pay no more than $\$ 1$, compared to $19 \%$ of high earners. It is noteworthy, however, that there is a good deal of dispersion even within the lowearning and high-earning groups. With this perspective on the general risk aversion of workers, let us now examine the results.

Hypothesis One: As the economic insecurity score increases, attitudes toward shared capitalism, preferences for variable pay, and workplace outcomes (behaviors) under shared incentives will worsen.

The sample is workers who say that they participate in any kind of shared capitalist practice, including company stock ownership of any kind, stock options, profit or gain sharing, or any combination of these. Table 2 shows the results and reports on a number of individual variables that measure attitudes towards shared rewards, preferences for more shared rewards, and workplace outcomes (behaviors) under shared reward situations. Some of the dependent variables are also grouped into summative attitude, preference, and outcome variables where a large sample size is amenable to such a grouping: 
Summative attitudes variable - measures a) how important it is to work in a company with employee ownership and b) how much the worker feels like an owner

Summative preferences variable- measures a) preference for variable pay (a 50/50 chance to make $10 \%$ more or $5 \%$ less over fixed pay); and, b) the preference for next pay increase as all fixed wages, a mixture of fixed and performance-based, or all performance-based pay

Summative outcomes (behaviors) variable - measures a) whether the worker is looking hard for a job with another company in the next year (reverse scored) ; b) the extent of their loyalty to their company ; c) whether they will work hard for the company; d) whether they plan to stay with their company for a long time; and, e) whether they see their current job as part of a long-term career

We will review these findings in some detail. The findings show that as the economic insecurity score increases, workers with increased risk respond with more negative attitudes about company ownership (Lines 1 to 16), weaker preferences for additional shared incentives in their company (Lines 17 to 28), and worse workplace outcomes. (Lines 29 to 39). A higher economic insecurity score is associated with very negative responses to shared capitalism just as Adam Smith's views would suggest.

Looking more closely at the individual measures of attitudes, as the economic insecurity score increases, workers report that it is less important to them to work for a company that provides stock ownership or stock options to its employees (Line 2), that they feel less like owners (Line 3), that ownership is less important to them (Line 4), that stock options were less important in attracting them to work for the company (Line 5), and that the Employee Stock Purchase Plan was less important in attracting them to work for the company (Line 6). (Note that the score does not predict that workers in ESOP companies said ESOPs were less likely to have attracted them to work for the company on line 7. This is probably because ESOPs under most circumstances do not require workers to buy the stock with their own capital.) As one would expect, as the economic insecurity score increases workers are more likely to say that a 
less risky cash incentive (Line 8), cash bonus (Line 13), or fixed wage increase (Line 14) will increase their motivation to improve the business success of the company. As the economic insecurity score increases, workers are less likely to be motivated to improve the business success of the company through more risky incentive practices such as open market purchases of company stock (Line 9), stock options (Line 10), an Employee Stock Purchase Plan (Line 11), a 401k plan company stock match (Line 15), a company-wide profit sharing plan (Line 16), or even a less risky ESOP (Line 12).

Regarding individual measures of preferences for additional shared incentives, as the economic insecurity score increases, workers are less willing to make a bet that risks losing $25 \%$ of fixed pay for a 50/50 chance of making 50\% more in variable pay (Line 19), wish their next pay increase to comprise fixed wages rather than a mixture of fixed/performance-based pay or all performance-based pay (Line 20), are unwilling to get company stock or stock options over cash incentives as part of their compensation (Line 21), and are unwilling to accept variable pay over fixed pay (Line 22). As the economic insecurity score increases, the percentage of fixed pay that they are willing to sacrifice for the chance of getting a possible $10 \%$ rise in variable pay goes down (Line 23). As the economic insecurity score increases, when asked to rank fixed pay, cash profit sharing, company stock or stock options as the preferred compensation mechanism for their next pay increase, workers rank less risky fixed pay higher and more risky company stock lower.

Regarding individual measures of workplace outcomes (behaviors), as the economic insecurity score increases, workers say they are more likely to: be looking for a job elsewhere in the next 6 months (Line 30), feel less loyalty to the company (Line 31), not see themselves working at the company for a long time (Line 32), and not see the company as part of a longtime 
career (Line 33). A higher economic insecurity score means more days absent in the last six months (Line 35). On other outcome measures reflecting contributing to the company, they say that they are less likely to: work harder for the company (Line 34) or have participated in teams or meetings where they offer suggestions to superiors on improving the company (Line 38).

Two related analyses available from the authors extend these findings. In one analysis we demonstrate that the results hold true for the typical combinations of shared capitalist practices that workers actually experience in the economy as identified by the University of Chicago's General Social Survey. So, for example, these results hold true for workers holding only company stock, for workers holding a combination of company stock, profit sharing, and broad-based stock options, and so forth. In another analysis we focus only on workers who own stock in $401 \mathrm{k}$ plans by measuring the percent of annual pay invested in company stock. We find that workers with high economic insecurity scores have more turnover, less loyalty, and less willingness to work hard at all levels of pay invested in company stock, not just at low levels of pay invested in company stock. The economic insecurity status appears to be the key to this subjective response. ${ }^{2}$ These tables are available from the authors.

Hypothesis Two: Lack of empowerment and poor employee relations help explain the negative relationship between the economic insecurity score and attitudestoward shared capitalism, preferences for variable pay, and behavioral outcomes under shared rewards.

The measurement of empowerment is the Lack of Empowerment Score. It is an additive index of each worker's participation in employee involvement teams, satisfaction with his or her work life influence overall, and satisfaction with influence in the job, department, and company as a whole. The measurement of employee relations is the Poor Employee Relations Score. It is an additive index of each worker's A-F school grades of their company regarding its 
trustworthiness in keeping its promises, overall employment relations, fairness, and ability to create a sense of common purpose in the company. (Both are reverse scored so that higher scores represent lower empowerment and worse employee relations. See appendix, variables 2131).

A first look at this issue is provided in Table 3 where worker reports of their expected turnover are compared to their scores on economic insecurity, empowerment, and employee relations. For ease of presentation, workers are divided into whether they are above or below the median on these three variables, and expected turnover is presented for the eight permutations. The highest likely turnover $(23.7 \%)$ is among those reporting high economic insecurity, poor empowerment, and poor employee relations, while the lowest $(3.9 \%)$ is among those in the opposite categories on all three variables. Overall, good employee relations appear most important, since workers report good employee relations in the four categories with the lowest likely turnover. In effect, at risk workers may respond less to this risk in better workplaces. Other tables available from the authors demonstrate the same pattern for loyalty and willingness to work hard.

Turning to the regressions in Table 4, the findings also show that a good corporate culture - the ability to have a say at work and be treated fairly in employment relations - plays a critical role in the relationship between the economic insecurity score and the attitude and behavioral outcomes. When lack of empowerment and poor employee relations are added as predictors of the summative attitudes measure, the economic insecurity coefficient goes down by almost 50\% (columns 1-2), and when they are added as predictors of the summative outcomes measure, the economic insecurity coefficient goes down by $70 \%$ (columns $7-8$ ). Lack of empowerment is also a significant predictor of the summative measure of preferences over 
variable pay, although the economic insecurity measure is not a significant predictor either before or after adding lack of empowerment as a control.

The two key implications of these findings are that: 1) a substantial portion of the negative attitudes toward shared capitalism and the poor behavioral outcomes among the economically insecure is not due to economic insecurity per se, but to corporate cultures that provide little empowerment and poor employee relations; and 2) the negative effects of economic insecurity can be counteracted by policies that increase employment and improve employee relations. Regarding the latter point, the magnitudes indicate that a one standard deviation improvement in either empowerment or employee relations would easily outweigh (by a multiple of two to six) a one standard deviation increase in economic insecurity in predicting the attitude and behavioural outcome index scores. ${ }^{3}$ These results paint a picture of worker risk that suggests that a bad and unfair corporate culture is itself seen as a risk by workers.

Hypothesis Three: The presence or absence of high performance work practices helps explain the negative effect of high economic insecurity scores on attitudes toward shared capitalism, preferences for variable pay, and behavioural outcomes under shared rewards.

The score for a high performance work system (HPWS) is based on the following summative index described in detail in the appendix, variables 32-38. It captures elements of training intensity, company communication and information, employee buy-in to corporate strategy, and structuring of the company's culture and work organization to support the overall company plan. A recent survey of the high performance work practices literature confirms the relevance of the components used (Blasi and Kruse 2007).

The method is to examine whether the negative coefficient on the economic insecurity score is reduced by the addition of HPWS as a control. As noted earlier, we contend that a more 
engaging work system will buffer worker response to risk. The results are in Table 4, columns 3, 6, and 9. The HPWS measure is a strong and significant predictor of all three summative measures. Controlling for HPWS, the negative coefficient of the economic insecurity score for the attitudes measure (column 3 ) is reduced by $50 \%$ relative to column 2 , and the coefficient is only one-fourth as large as it was before controlling for lack of empowerment, poor employee relations, and HPWS (column 1). It appears that workers have more willingness to have a profit or stock share in their company if they perceive that the company invests more in their performance abilities through a high performance work system. Adding HPWS as a predictor of the summative outcomes measure (column 9) reduces the economic insecurity coefficient by only a small amount relative to column 8 , but the fact that HPWS is closely related to lack of empowerment and poor employee relations (reducing the coefficients on those variables when it is added in column 9) indicates that HPWS is a key factor in reducing the economic insecurity effect found in column 7. The results strongly suggest that high risk workers moderate their responses to risk when the work system is more progressive.

It has been demonstrated that as economic insecurity of workers rises, this is associated with worse worker attitudes toward shared capitalism, preferences for variable pay, and behavioural outcomes under shared capitalist arrangements. Not only do workers make some bad portfolio decisions under shared capitalism as the research literature reviewed in the beginning of this study has shown, but our results indicate that their level of economic insecurity also influences how well they actually respond to shared capitalist arrangements such as employee ownership in their workplace. Insecure workers may moderate their responses in better workplaces. One implication is that employee ownership and shared capitalist plans need to be designed carefully when they involve workers with high economic insecurity. Employers with 
shared capitalist arrangements that are structured to take into account worker responses to their economic insecurity and employment culture should, as a result, have better worker attitudes, better workplace outcomes, and a greater willingness of workers to prefer such arrangements. This means, for example, that pushing low paid workers with little wealth who perceive that they are paid non-competitive wages to buy company stock in 401(k) plans with their savings does not make economic sense for the workers, the firms, the shareholders, or the economy as a whole, because asking workers with little capital to risk their personal capital is associated with a bad worker response to shared capitalism.

\section{Is Shared Capitalism Consistent With Proper Diversification?}

Does the portfolio diversification problem go away now that we know that workers tend to subjectively respond poorly to excessive economic insecurity under shared capitalist arrangements? The answer is clearly no, it does not go away. Our results only show that workers are subjectively sensitive to risk, and manage to respond to it in their own way. The results do not mean that workers' investment portfolios always properly diversify risk. Indeed, the irony of our results is that, while workers evidently respond to their subjective risk, the problem of objective risk in their portfolios remains. The fact that workers in the more progressive workplaces respond less to risk, only increases the importance of solving the objective risk problem.

The concerns of economists and policy makers about an objective lack of diversification in workers' portfolios thus needs to be considered more carefully. In the NBER sample the median percent of net wealth in company stock is $5 \%$ and the mean is $14 \%$. While only $0.6 \%$ of workers have $100 \%$ of their net wealth in company stock (i.e. Muelbroek's scenario), $4.7 \%$ of 
NBER sample workers do have more than $50 \%$ of their net wealth in company stock, and $15.6 \%$ have more than twice the mean percent of net wealth in company stock, that is, have over $28 \%$ of their net wealth invested in company stock. Thus, it is likely that at least these three groups -- in total, $20.9 \%$ of the workers in the NBER employee survey sample -- may have excessive amounts of company stock in their overall portfolios. We can consider these groups to be approximately the workers for whom employee ownership plays a critical role in lack of diversification.

The remainder of this section explores the question of how much investment in company stock is "too much."

The theory of rational behavior under uncertainty, as developed by Leonard J. Savage (1954), asserts that the rational decision maker maximizes expected utility using probability beliefs where objective probabilities are not known. Levy and Markowitz (1979) show that, for a wide variety of risk-averse utility functions and historical return distributions, mean-variance approximations provide almost maximum expected utility. (See also Markowitz 1959, Chapters 6 and 13; Dexter, Yu and Ziemba 1980; Ederington 1986; Hlawitschka 1994; Kroll, Levy and Markowitz 1984; Markowitz, Reid and Tew 1994; Pulley 1981, 1983; and Simaan 1993.) Thus the justification for the use of mean-variance, according to Markowitz (1959) and others, is not that probability distributions are Gaussian or that utility is quadratic (as asserted as requirements in Tobin 1958 and frequently incorrectly attributed to Markowitz), but as an approximation to expected utility.

The mean-variance approximation to expected utility typically takes the form

$$
E U \cong E-\frac{1}{2} k V
$$


where $E$ is the expected and $V$ the variance of returns on the portfolio-as-a-whole, and $k>0$ is a risk-aversion parameter. For example, following Kelly (1956) and Latané (1957), most financial analysts believe that action for the long run involves maximizing the expected value of the $\log$ of $1.0+$ return. Levy and Markowitz show that this is closely approximated by Equation (1) with $\mathrm{k}=1.0$. In continuous time models, "Ito's Lemma" asserts that this relationship is exact quite generally.

If $X$ is the fraction of an employee's financial assets held "explicitly" in company stock and $(1-X)$ the fraction in all other financial assets (including, e.g., an index fund which "implicitly" owns the company stock) then

$$
\begin{aligned}
& E=m_{1} X+m_{2}(1-X) \\
& V=V_{1} X^{2}+V_{2}(1-X)^{2}+2 X(1-X) \sigma_{12}
\end{aligned}
$$

where $m_{1}$ and $m_{2}$ are the expected (or mean) returns on the two "investments," $V_{1}$ and $V_{2}$ their variances and $\sigma_{12}$ their covariance. The latter includes the covariance between the company stock held explicitly and that held implicitly. Inserting (2) into (1) we have

$$
\begin{aligned}
E U \cong & m_{1} X+m_{2}(1-X) \\
& -\frac{1}{2} k\left\{V_{1} X^{2}+V_{2}(1-X)^{2}+2 \sigma_{12} X(1-X)\right\}
\end{aligned}
$$

The optimum value of $X$ is found by setting the derivative of $E U$ to zero, from which emerges that $\hat{X}$, the optimum $X$, satisfies

$$
\hat{X}\left(V_{1}+V_{2}-2 \sigma_{12}\right)+V_{2}-\sigma_{12}=\left(m_{1}-m_{2}\right) / k
$$

The analysis simplifies considerably if we assume that $\hat{X}=0$, and $m_{1}=m_{2}$ absent any stock incentive plan. The first equality is plausible; since "other investments" may include the company's stock, we may assume that it includes the ideal amount of this stock, in which case 
indeed $\hat{X}=0$. Later we discuss the assumption that $m_{1}=m_{2}$. Given these two assumptions, Equation (4) implies that

$$
\sigma_{12}=V_{2}
$$

From this follows that (3) may be written as

$$
E U \cong m+\left(\Delta m_{1}\right) X-\frac{1}{2} k\left\{V_{1} X^{2}+V_{2}\left(1-X^{2}\right)\right\}
$$

with $m=m_{1}=m_{2}$ and $\Delta m_{1}=0$.

We are interested here in the tradeoff between increased $m_{1}$ (keeping $m_{2}$ constant) and increased $X$, moving the investor's allocation from the optimum at $X=0$. As $m_{1}=m+\Delta m_{1}$ increases $\hat{X}$, the optimum $X$, increases as well. Specifically, differentiating (6) with respect to $X$, and setting $d E U / d X$ to zero, we find

$$
\hat{X}=\Delta m_{1} / k\left(V_{1}-V_{2}\right)
$$

The term $\left(V_{1}-V_{2}\right)$ in the denominator of Equation (7) may seem strange. For example, if $V_{1}=V_{2}$ the formula implies infinite $\hat{X}$. But (5) implies

$$
\begin{aligned}
V_{2} & =\sigma_{2}{ }^{2} \\
& =\rho_{1} \sigma_{1} \sigma_{2}
\end{aligned}
$$

therefore

$$
\sigma_{2}=\rho \sigma_{1}
$$

Thus $V_{2}<V_{1}$ unless the two "investments" are perfectly correlated.

The assumption that $m_{1}=m_{2}$ may be plausible if $(1-X)$ represents investment in other equities, but not if it includes substantial investment in money market funds or short term bonds. 
Then we would expect $m_{2}<m_{1}$. A standard and very convenient assumption is that $X$ and $1-X$ represent investments in risky "securities" and, additionally, the investor's risk level is adjusted by holding cash with interest rate $r_{0}$. In this case, the Tobin Separation Theorem is applicable. If the investor can borrow as well as lend at the rate $r_{0}$, as Sharpe (1964) assumes, then the investor will hold the risky portfolio which maximizes the Sharpe ratio

$$
\frac{E-r_{0}}{\sigma}
$$

where $\sigma$ is the standard deviation of portfolio return. If the investor can only lend not borrow at the rate $r_{0}$, as Tobin (1958) assumes, and "cash" is part of the investor's portfolio then, again, the investor holds the risky portfolio that maximizes the Sharpe ratio and combines it with lending (i.e., the holding of cash).

In general in this case, the optimum risky portfolio satisfies

$$
C Y=b v
$$

where $C$ is the covariance matrix among risky securities, $Y$ is the portfolio of risky securities, $v$ is a vector of excess returns (i.e., expected returns minus the risk-free rate), and $b$ is a number (as distinguished from a vector or matrix). In our case Equation (10) specializes to

$$
\left(\begin{array}{cc}
V_{1} & \rho^{2} V_{1} \\
\rho^{2} V_{1} & \rho^{2} V_{1}
\end{array}\right)\left(\begin{array}{l}
X_{1} \\
X_{2}
\end{array}\right)=b\left(\begin{array}{l}
v_{1} \\
v_{2}
\end{array}\right)
$$

where we write $X_{1}$ and $X_{2}$ for $X$ and $1-X$ respectively. Solving Equation (11) gives us

$$
\begin{aligned}
& X_{1}=b\left(v_{1}-v_{2}\right) /\left(1-\rho^{2}\right) V_{1} \\
& X_{2}=b\left(v_{2}-\rho^{2} v_{1}\right) / \rho^{2}\left(1-\rho^{2}\right) V_{1}
\end{aligned}
$$

If $b=\rho^{2} V_{1} / v_{2}=V_{2} / v_{2}$ then $X_{1}+X_{2}=1$. A smaller $b$ implies that "cash" equal $1-X_{1}-X_{2}$ is held. 
A plausible example might have $\sigma_{2}=0.2, \sigma_{1}=0.4$. (The former is approximately the standard deviation of the S\&P 500 Index; the latter then would follow from a one-factor model

$$
r_{1}=\alpha+\beta r+u
$$

with $r_{1}$ representing the return on company stock; $r$ that on an underlying factor with the same variance as the $\mathrm{S} \& \mathrm{P} 500 ; \beta=1$ and the variance of the idiosyncratic term $u$ equal three times that to the variance of $r$.) Then (8b) implies $\rho=\frac{1}{2}$.

Solving for $X=X_{1}$ in (12) with these parameters yields

$$
3 X=\frac{v_{1}-v_{2}}{v_{2}}
$$

For example if $(1-X)$ supplied four percentage points of excess return and $X$ supplied five, then

$$
\hat{X}=0.067
$$

A higher $X$, in the neighborhood of ten or even fifteen percent, would not be imprudent. Because the relationship between $V$ and $X$ is quadratic, small deviations from zero, the optimum if $m_{1}=m_{2}$, do not increase $V$ or reduce EU much, even if $m_{1}=m_{2}$. Specifically, Equation (6) implies

$$
V=V_{2}+\left(V_{1}-V_{2}\right) X^{2}
$$

and

$$
\frac{d V}{d X}=2\left(V_{1}-V_{2}\right) X
$$

Thus at $X=0, d V / d X=0$. A small increase in $X$ has virtually no effect on $V$. 
Table 5 shows the values of portfolio $V$ and $\sigma$ for various values of $X$ for the parameters of our example. Figure 1 plots the relationship between $\sigma$ and X. These reinforce the observation that $X$ around ten percent has small effect of the volatility of the employee's portfolio. For example, a ten percent investment in company stock has a standard deviation of 20.3 percent, whereas a fifteen percent investment in company stock has a standard deviation of return of 20.7 percent, up slightly from 20.0 percent for no company stock as compared to 40.0 percent for all company stock.

The difference between the $6 \frac{2}{3}$ percent, which is optimal in this example, and the ten or fifteen percent which is not too imprudent, suggests a possible "free-rider" problem. From the individual employee's point of view, ideally he or she would like everyone else to have ten or fifteen percent invested and have $6 \frac{2}{3}$ invested himself or herself.

$V, \sigma$ and $E U$ are continuous functions of the input parameters; thus small changes in the assumptions of this example cause small changes in the table and the figure. Thus it seems likely that any reasonable estimates will leave our general conclusion in tact: A small but meaningful employee stock ownership level will not significantly deteriorate the diversification of employee portfolios.

\section{Conclusion}

These exploratory insights on the role of risk in properly structuring shared capitalist arrangements have been developed by studying how workers themselves would confront and resolve the issue of risk and examining the implications of portfolio theory. The main revision to the previous empirical research on the economics of employee ownership is that a high level of risk is not a requirement of making shared capitalism work best. The results show clearly that 
excessive worker risk based on a worker's level of economic insecurity has the capability of reversing every single positive individual and workplace outcome documented in decades of research on shared capitalism and in findings in companion research using these data. Lack of empowerment and poor employee relations play key roles in driving the negative impact of risk. Ironically, workers in corporations with the most progressive work practices may not pay as much attention to their risk as their objective economic situation requires.

This finding may partly explain why empirical results on the impact of employee ownership on firm performance are not always uniformly positive and sometimes show dispersion, why some of the most progressive corporations ignore these issues, and why some very large and very risky employee ownership experiments have failed miserably. The most notable failure is the United Airlines employee buyout where risking the capital of individual workers, wage substitution, lack of empowerment and poor employee relations all played a large role consistent with our analysis. Indeed, the design of United Airlines employee ownership plan appears to have violated every finding of this study. Moreover, many United workers may have also had undiversified portfolios. Worker economic insecurity has been an unmeasured variable in past research. Two clear implications are that: 1) the structure of employee ownership and profit sharing plans needs to be "fit" to the risk profile of the workers; and (2) portfolio diversification can be generally consistent with shared capitalism.

Eliminating shared capitalism from capitalist societies is not the answer to the problem of objective risk. Remember that Adam Smith emphasizes the incentive effect of capitalism and its superiority to feudal systems and expected shared capitalism to be a positive motivator. Portfolio theory suggests how a wide range of workers could have employee ownership and diversification at the same time. Portfolio theory's implications for this discussion is sometimes 
reduced in the popular mind to the quick summary "buy a index of the entire market" but, as we have seen, this is not precisely what portfolio theory says. Portfolio theory does not propose that all risk be banned so that every global citizen should own a completely diversified basket of securitized assets worldwide. In such a world there would be no home ownership, no individual asset ownership, no sole proprietorships, no small businesspeople, no entrepreneurs, no high tech start-ups, no owners who are "principals" in corporations, no room for workers to have shares in their company, indeed, no shared capitalism. There would, in short, be no capitalism in the individual incentive sense. It would be something akin to the heavily controlled paternalistic risk reduction of feudalism.

Research on employee ownership and shared capitalism often ignores or minimizes both subjective and objective risk. This disregard has taken place for decades despite the fact that excessive risk and lack of diversification has been the principal objection by some economists, other social scientists, and policy-makers to the idea of broadened shared incentives and employee ownership. The goal of this paper has been to confront these objections head-on and attempt through empirical analysis to understand them better. As national wage systems evolve in the $21^{\text {st }}$ century and inflation-adjusted wage increases flatten, the additional income workers can get from capital income (shares of profits and stock and capital appreciation in their firms), may constitute an important potential future component of worker wealth. Risk is not the enemy of shared capitalism, but the elements of this risk must be directly confronted, empirically understood, and theoretically considered in a sound manner.

\section{Notes:}

1 The authors are indebted to Mark Huselid for suggesting what themes and wording should be considered as critical for our questions regarding the measurement of alignment with the 
company's strategy. While we did some editing to make the questions accessible to the wide variety of workers and firms in the study, they basically follow his ideas.

2 In a discussion of these findings with Daniel Kahneman, he has raised the issue whether the (different) ideas of an irrelevant gift (one that does not respond to an immediate need) or of a gift that involves costs to the recipient, have anything to do with what we found. (Personal communication, October 26, 2007)

3 In predicting the summative attitudes measure (column 2), the effect of a one standard deviation change in the empowerment score (employee relations score) on the ordered probit index would be 2.14 (2.91) times larger than the effect of a one standard deviation change in the insecurity score. In predicting the behavioral outcomes measure (column 8), the similar multiples would respectively be 4.03 and 6.59 . 


\section{Appendix: Variable Definitions and Descriptive Statistics.}

\section{Dependent Variables}

\section{$\underline{\text { Risk Aversion and Risk Seeking }}$}

1. Attitude towards risk: "Some people like to take risks and others dislike taking risks. Where would you place yourself on a scale of how much you like or dislike taking risks, where 0 is hating to take any kind of risk and 10 is loving to take risks?" $(0-10$ scale, $0=$ Hate to take risks $10=$ Love to take risks). Mean $=5.61$, s.d. $=2.38, n=34,794$.

2. Highest price paid for a bet: "You are offered a bet. You have a 10\% chance of winning $\$ 1000$. Would you take the bet if it cost you: (mark highest price you would pay: $\$ 0, \$ 1, \$ 10$, $\$ 20, \$ 50, \$ 100, \$ 150) \quad$ Mean $=\$ 23.37$, s.d. $=32.40, \mathrm{n}=34,751$.

\section{Outcomes}

3. Planning to stay with employer vs looking to turnover. : "How likely is it that you will decide to look hard for a job with another organization within the next twelve months?" 0-3 scale, $0=$ Already looking; $1=$ Very likely; $2=$ Somewhat likely; $2=$ Not at all likely. Mean $=2 . .45$, s.d. $=$ $.81, \mathrm{n}=35,080$.

4. Extent of loyalty to current employer: "How much loyalty would you say you feel toward the company you work for as a whole?" (Scale $0-3,0=$ No loyalty at all; $1=$ Only a little; $2=$ Some; $3=$ A lot). Mean $=2.37$, s.d. $=.78, n=34,555$.

5. Willingness to work harder to help company succeed: "To what extent do you agree or disagree with this statement? "I am willing to work harder than I have to in order to help the company I work for succeed." (Scale: $0-4,0=$ Strongly disagree; $1=$ Disagree; $2=$ Neither agree nor disagree; 3= Agree; 4= Strongly agree) Mean=3.04, s.d. 0.89; $\mathrm{n}=35,091$.

6. Whether worker expects to stay with employer for the foreseeable future: "Which ONE of the following statements best describes how you think of your current employer? $1=$ I see myself working here for the foreseeable future (a long time). $0=\mathrm{I}$ do not see myself working here very long." (Scale 0-1). Mean=0.83; s.d=0.37; $n=34,794$.

7. Whether worker sees current job as part of long-term career: "Thinking about your current job (rather than your employer), do you look upon it as part of your long term career, or a position that is not part of your long term career? $1=$ Part of my long term career; $0=$ A position that is not part of my long term career." (Scale 0-1). Mean=0.78, s.d. 0.42, n=34,991.

8. Summative outcomes variable: Additive index of variables 3-7 above. (0-12 scale) Mean = 9.49, s.d. $=2.26, \mathrm{n}=33,467$. 


\section{$\underline{\text { Attitudes }}$}

9. Importance of employee ownership: "How important is it to you to work in a company that provides stock ownership to its employees? Please rate on a scale of 0 to $10 . "$ ( $(0-10$ scale, $0=$ Not important $-10=$ Highly important.) Mean $=7.44$, s.d. $=2.68, \mathrm{n}=34,729$.

10. Feeling like an owner of the company: "How much do you feel like an owner of this company?" (1-10 scale, $1=$ Not important --- A moderate degree --- 10=Very much). Mean = 4.81 , s.d. $=3.02, \mathrm{n}=34,910$.

11.. Summative attitudes variable: Additive index of variables $9-10$ above. $(0-20$ scale $)$ Mean $=$ 12.24, s.d. $=4.93, \mathrm{n}=34,525$.

\section{$\underline{\text { Preferences }}$}

12. Preference regarding a small variable pay risk: "We would like to ask about your attitude toward variable pay in two imaginary jobs. Job A and Job B are identical except for the fact that Job A pays a fixed amount and Job B pays an amount that varies. Based on the following information, which one would you choose? Job A which guarantees an amount equal to your current pay, or Job B, which each year has a 50/50 chance that you would make $10 \%$ MORE than your current pay and a 50/50 chance that you would make 5\% LESS than your current pay." (Scale: $0=$ Job A, $1=$ Job B). Mean $=0.40$ s.d. $=0.49, \mathrm{n}=28,700$.

13. Preference regarding variable or fixed pay for next pay increase: "For your next pay increase, would you prefer that it come in the form of: 1.All fixed wages, with no profit sharing or company stock. 2. Split between fixed wages and profit sharing or company stock. 3 . All in the form of profit sharing or company stock." (Scale: 1-3, textual responses as shown.) Mean = 1.84 , s.d. $=.60, \mathrm{n}=22,623$.

14. Summative preferences variable: Additive index of variables $12-13$ above. (0-4 scale) Mean $=2.22$, s.d. $=0.81, \mathrm{n}=21,040$.

15. Incentive threshold point: "Some people think that basing pay on company performance will encourage employees to take an active role in promoting the company's success. At your company, how much of their pay would most employees have to get in performance-based pay to motivate them to take more responsibility for the success of the company? $5 \%, \ldots 10 \%, 20 \%$, _30\%,_40\%, 50\%, 60\%, _70\%,_80\%, $90 \%$, $100 \%$, Performance-based pay would not make a difference." (Scale: $\%$ 0-100\%). Mean $=31.7$, s.d. $=24.6, \mathrm{n}=25435$.

16. Percent of worker's wealth in equities overall: "About what percent of your total wealth is in stocks overall? \%" (Scale: 1-100\%). Mean: 29.2, s.d=26.6; $n=25,715$.

\section{Independent Variables}

17. Economic insecurity score. Measure of the economic status quo of each worker denoting increasing economic insecurity. Summative measure of questions 18-20 below including: 
-quartiles representing highest to lowest annual fixed pay plus overtime

Score: $0-3$

-quartiles representing highest to lowest total wealth divided by fixed pay Score: 0-3

-five categories representing highest to lowest competitiveness of fixed pay Score: 0-4

Mean=5.28, s.d. $=2.12 ; \mathrm{n}=22,980$. Minimum 0; Maximum 10.

18. Annual fixed pay plus overtime: "What was your annual base pay last year (excluding any overtime, bonuses and commissions) BEFORE taxes and deductions? If you receive overtime pay, how much did you earn in overtime last year?" Mean=60,035, s.d. $=42,092$, $\mathrm{n}=28,365$.

For first component of the economic insecurity score, answers were recoded by quartile: $0:>\$ 80,000 ; 1:>\$ 50,000 \&<=\$ 80,000 ; 2:>\$ 33,000 \&<=\$ 50,0003:<\$ 33,000$.

19. Total wealth (minus debts) with spouse/partner: "People have various assets that constitute their wealth. These include the value of their house minus the mortgage, plus their vehicles, stocks and mutual funds, cash, checking accounts, retirement accounts including 401(k) and pension assets, and so forth. Taking account of all of these things would you say that the WEALTH of you and your spouse/partner is: Less than $\$ 5000 ; \$ 5000$ to $\$ 20,000 ; \$ 20,000$ to $\$ 40,000 ; \$ 40,000$ to $\$ 75,000 ; \$ 75,000$ to $\$ 100,000 ; \$ 100,000$ to $\$ 150,000 ; \$ 150,000$ to $\$ 250,000 ; \$ 250,000$ to $\$ 500,000 ; \$ 500,000$ to $\$ 1$ Million; Over $\$ 1$ Million." For analytical purposes, each worker was assigned the mid-point of each category as their assumed wealth. Mean $=312020$, s.d. $=613,975, \mathrm{n}=28,920$.

For second component of the economic insecurity score, answers were divided by fixed pay plus overtime, and recoded into quartiles: $0:>6.37 ; 1:>3.09 \&<=6.37 ; 2:>1.28 \&<$ $=3.093:<1.28$

20. Competitiveness of annual fixed pay: "Do you believe your fixed annual wages last year were higher or lower than those of employees with similar experience and job descriptions in other companies in your region? Please circle a number from 1 to 5 ." Mean=2.67, s.d. $=1.00, \mathrm{n}=31.091$.

For third component of the economic insecurity score, answers were subtracted from 5 for a range of 0 to 4 .

\section{Other Variables}

21. Lack of Empowerment Score: Summative measure of 22-26 below (reverse scored from format used in survey):

- Overall satisfaction with job-related influence

Score $0-3$

-Worker influence at the job level

Score $0-3$

-Worker influence at the work group or department level

Score $0-3$

-Worker influence at the company level

Score $0-3$ 
-Worker involvement in a team, committee, or task force

Score $0-1$

Mean=6.07, s.d.=2.66, $\mathrm{n}=33,855$; Minimum 0; Maximum 13.

22. Overall satisfaction with job-related influence. "Overall, how satisfied are you with the influence you have in company decisions that affect your job and work life?" (Scale 0-3, $0=$ very satisfied, $1=$ somewhat satisfied, $2=$ not too satisfied, $3=$ not at all satisfied) Mean= 1.36; s.d. $=0.84, \mathrm{n}=34,981$.

23. Worker influence at the job level. "How much involvement and direct influence do YOU have in: A. Deciding how to do your job and organize the work." (Scale: 0-3, 0=A lot, $1=$ Some, $2=$ Only a little, $3=$ None) Mean=0.69, s.d. $=0.86, \mathrm{n}=35,109$.

24. Worker influence at the work group or department level. "How much involvement and direct influence do YOU have in: B. Setting goals for your work group or department." (Scale: 0$3,0=\mathrm{A}$ lot, $1=$ Some, $2=$ Only a little, $3=$ None). Mean=1.38, s.d.=1.03, $\mathrm{n}=35,015$..

25. Worker influence at the company level. "How much involvement and direct influence do YOU have in: C. Overall company decisions." (Scale: 0-3, 0=A lot, 1=Some, 2= Only a little, $3=$ None). Mean=2.28, s.d. $=0.86, \mathrm{n}=34,978$.

26. Worker involvement in a team, committee, or task force: "Some companies have organized workplace decision-making in ways to get more employee input and involvement. Are you personally involved in any team, committee or task force that addresses issues such as product quality, cost cutting, productivity, health and safety, or other workplace issues? (Scale: $0=$ yes; $1=$ no). Mean: 0.37, s.d. $=0.48, \mathrm{n}=34,722$.

27. Poor Employee Relations Score: Summative measure of 28-31 below (reverse scored from format used in survey):

-company grade for trustworthiness in keeping its promises

Score $0-4$

-company grade for overall employment relations

Score $0-4$

-company grade for fairness

Score 0-6

-company grade for creating a sense of common purpose in the company Score 0-4

Mean=6.75, s.d. 4.14, n=34,199; minimum 0; maximum 18 .

28. Worker's grade of company for trustworthiness: "If you were to rate how well this company takes care of workers on a scale similar to school grades, what grade would you give in these areas? ( $\mathrm{C}$ is an average grade.) Trustworthiness in keeping its promises." (Scale: $\mathrm{A}=$ $0 ; \mathrm{B}=1 ; \mathrm{C}=2 ; \mathrm{D}=3 ; \mathrm{F}=4)$. Mean=1.62, s.d.=1.14, $\mathrm{n}=34,850$.

29. Worker's grade of company for fairness: "Overall, this company is fair to its employees." (Scale: Strongly agree $=0$, Strongly disagree $=6$ ). Mean=2.14, s.d.=1.67, $n=35,031$.

30. Worker's grade of company for overall employment relations: "If you were to rate how well this company takes care of workers on a scale similar to school grades, what grade would 
you give in these areas? ( $\mathrm{C}$ is an average grade.) Overall relations with employees." (Scale: $\mathrm{A}=0 ; \mathrm{B}=1 ; \mathrm{C}=2 ; \mathrm{D}=3 ; \mathrm{F}=4$ ). Mean: 1.51, s.d. 1.05, $\mathrm{n}=34,928$.

31. Worker's grade of company for creating a sense of common purpose: "If you were to rate how well this company takes care of workers on a scale similar to school grades, what grade would you give in these areas? ( $\mathrm{C}$ is an average grade.) Creating a sense of common purpose in the company." (Scale: $\mathrm{A}=0 ; \mathrm{B}=1 ; \mathrm{C}=2 ; \mathrm{D}=3 ; \mathrm{F}=4$ ). Mean: 1.50 , s.d. $1.04, \mathrm{n}=34,916$.

32. High Performance Work System: Summative measure of 33-38 below:

-whether workers have received formal training from their employer in the last 12 months -the number of hours of this training measured by four increasing categories of investment by the firm

-whether workers say they understand their company's overall plan for being successful -whether workers say that they agree with this plan

-whether workers say that the company is providing them with the information, training, and resources necessary to help achieve the goals of this plan

-whether workers feel that the company's culture encourages you to share your ideas about how to achieve the goals of this plan

Mean $=13.35$, s.d. $=3.31, \mathrm{n}=23,714$.

33. Whether worker received formal training by employer. "In the last 12 months have you received any formal training from your current employer, such as in classes or seminars sponsored by the employer?" (Score: $0=$ No; $1=$ Yes). Mean=0.59, s.d. 0.49, $\mathrm{n}=34,913$.

34. Hours of formal training in last 12 months: "About how many hours of formal training have you received in the last 12 months?" (Scale: actual number of hours). Mean=18.88, s.d. $=41.57, \mathrm{n}=34,154$.

Recoding for training hours variable into four ascending categories:
0: 0 hours
1: $>0 \&<=11$ hours
$41.0 \%$
2: $>11 \&<=33$ hours
$17.6 \%$
3: $>33 \&<1680$ hours
$18.5 \%$
$22.8 \%$

Percent of Sample With This Score

35. Whether worker says he/she understands company's overall plan: "To what extent do you: Understand your company's overall plan for being successful?" (Scale: 1-4, 1=not at all, $2=$ very little, $3=$ to some extent, $4=$ to a great extent). Mean=3.18, s.d. $=0.72, n=25,046$.

36. Whether worker says she/he agrees with company's overall plan: "To what extent do you: personally agree with this plan?" (Scale: $1-4,1=$ not at all, $2=$ very little, $3=$ to some extent, $4=$ to a great extent). Mean=3.02, s.d. $=-.73, \mathrm{n}=24,515$.

37. Whether worker says he/she has info, training, and resources to achieve the company's overall plan. "To what extent do you: Feel that the company is providing you with the 
information, training, and resources necessary to help achieve the goals of this plan?" (Scale: 1-4, 1=not at all, 2=very little, $3=$ to some extent, $4=$ to a great extent).

Mean=2.84, s.d. $=0.83, \mathrm{n}=24,906$.

38. Whether worker feels company culture encourages sharing of ideas about achieving plan's goals. "To what extent do you: Feel that your company's culture encourages you to share your ideas about how to achieve the goals of this plan?" (Scale: 1-4, 1=not at all, 2=very little, $3=$ to some extent, $4=$ to a great extent). Mean=2.74, s.d. $=0.91, n=24,841$.

39. Percent of wealth in company stock: "About what percent of your wealth is in your employer's stock?" (Scale: 0-100\%). Mean=16.9, s.d. $=21.2, \mathrm{n}=26,818$. 


\section{Bibliography}

Akerlof, George A. 1979. "The case against conservative macroeconomics: an inaugural lecture," Economica 46, 219-237 (August)

Appelbaum, Eileen, Thomas Bailey, Peter Berg, and Arne L. Kalleberg. 2000. Manufacturing Advantage: Why High Performance Work Systems Pay Off. Ithaca, N.Y.: Cornell University Press/ILR Press.

Arrow, Kenneth. 1973. "Social responsibility and economic efficiency," Public Policy 21: 303317 (Summer).

Bartholomew, David. 1996. The Statistical Approach to Social Measurement. New York: Academic Press.

Bartholomew, David, J. Galbraith, Irini Moustkaki, Fionay Steele. 2002. The Analysis and Interpretation of Multivariate Data for Social Scientists. Chapman and Hall/CRC.

Becker, Brian E., and Mark A. Huselid, and Dave Ulrich. 2001. The HR Scorecard: Linking People, Strategy, and Performance. Cambridge: Harvard Business School Press.

Benartzi, Shlomo. 2001. "Excessive extrapolation and the allocation of company stock to retirement accounts, “ Journal of Finance 56(5), 1747-1764.

Benartzi, Shlomo and Richard Thaler. 2001. "Naïve diversification strategies in defin ed contribution savings plans," American Economic Review 91(1), 79-98.

Bernstein, Peter L. 1992. Capital Ideas: The Improbable Origins of Modern Wall Street. New York: The Free Press.

Blasi, Joseph and Douglas Kruse. 2006. "High Performance Work Practices at Century's End," Industrial Relations, October. Vol. 45, No. 4, pp. 547-578.

Blasi, Joseph, Richard Freeman, Chris Mackin, and Douglas Kruse. 2008. "Creating a Bigger Pie? The Effects of Employee Ownership, Profit Sharing, and Stock Options on Workplace Performance." Presented at NBER/Russell Sage Foundation conference, New York, NY, October 2006.

Cappelli, Peter, and David Neumark. 2001. "Do "High-Performance" Work Practices Improve Establishment-Level Outcomes?," Industrial and Labor Relations Review, Volume 54, Number 4, July.

Dexter, A.S., J.N.W. Yu and W. T. Ziemba. 1980. "Portfolio Selection in a Lognormal Market When the Investor Has a Power Utility Function: Computational Results" In M.A.H. Dempster (ed.), Stochastic Programming, Academic Press, New York, pp.507-23 
Ederington, L.H. 1986. "Mean-variance as an Approximation to Expected Utility Maximization," working paper 86-5, School of Business Administration, Washington University, St Louis, Missouri.

Freeman, Richard, Douglas Kruse, and Joseph Blasi. 2008. "Worker Responses to Shirking under Shared Capitalism." Presented at NBER/Russell Sage Foundation conference, New York, NY, October 2006.

Harden, Erika, Douglas Kruse, and Joseph Blasi. 2008. "Who Has a Better Idea: Innovation, Shared Capitalism, and Human Resource Policies." Presented at NBER/Russell Sage Foundation conference, New York, NY, October 2006.

Hlawitschka, Walter. 1994. "The Empirical Nature of Taylor-Series Approximations to Expected Utility," The American Economic Review Vol. 84, No. 3 pp.713-719

Ichniowski, Casey, Kathryn Shaw, and Giovanni Prennushi. 1995. The Impact of Human Resource Management Practices on Productivity. Cambridge, Massachusetts: National Bureau of Economic Research, Working Paper Number 5333.

Kahneman, Daniel. 2003. "A psychological perspective on economics," American Economic Review, 92(2), 161-168 (May).

Kahneman, Daniel, Jack L. Knetsch, and Richard Thaler. 1986a. "Fairness as a constraint on profit seeking: entitlements in the market," American Economic Review 76(4), 728-741 (September).

Kahneman, Daniel, Jack L. Knetsch, and Richard Thaler. 1986b. "Fairness and the assumptions of economics," Journal of Business 59(4), Part 2, S285-S300 (October)

Kahneman, Daniel, Jack L. Knetsch, and Richard Thaler. 1991. "Anomalies: The Endowment Effect, Loss Aversion, and Status Quo Bias," Journal of Economic Perspectives, Volume 5, Issue 1, Winter 1991, 193-206

Kahneman, Daniel and Amos Tversky. 1979. "Prespect theory: an analysis of decisions under risk," Econometrica 47(2), 313-27 (March).

Kahneman, Daniel and Amos Tversky. 2000. Choices, values, and frames. New York: Cambridge University Press.

Kallberg, Jarl G., and William T. Ziemba. 1981. "Remarks on Optimal Portfolio Selection," in Methods of Operations Research, Gunter Bamberg and Otto Optiz (eds.). Cambridge, MA: Oelgeschlager, Gunn \& Hain pp. 507-520.

Kelly, J. L., Jr. 1956. “A New Interpretation of Information Rate,” Bell System Technical Journal, pp. 917-926 
Keynes, John Maynard. 1983. "Letter to F.C. Scott, February 6, 1942," The Collected Writings of John Maynard Keynes, Donald Moggridge, ed., Vol XII, New York: Cambridge University Press, pps. 81-83.

Kroll, Y., H. Levy and H.M. Markowitz. 1984. "Mean Variance Versus Direct Utility Maximization," Journal of Finance, 39(1), March.

Kruse, Douglas, Joseph Blasi, and Rhokeun Park. 2008. "Shared Capitalism in the U.S. Economy: Prevalence, Characteristics, and Employee Views of Financial Participation in Enterprises." Presented at NBER/Russell Sage Foundation conference, New York, NY, October 2006.

Laffont, Jean-Jacques, and David Martimort. 2002. The Theory of Incentives: The PrincipalAgent Model. Princeton, N.J.: Princeton University Press.

Latané, H. A. 1959. “Criteria for Choice among Risky Ventures,” Journal of Political Economy, April, LXVII No. 2, pp. 144-155

Levy, H. and H.M. Markowitz. 1979. "Approximating Expected Utility by a Function of Mean and Variance," American Economic Review, 69(3), June pp. 308-317.

Markowitz, Harry. 1952a. "Portfolio Selection,” Journal of Finance, Vol 2 (1), 79-91.

Markowitz, Harry. 1952b. "The Utility of Wealth,” The Journal of Political Economy, Vol. 60 (2), 151-158.

Markowitz, H.M. 1959. Portfolio Selection: Efficient Diversification of Investments. Wiley, Yale University Press, 1970, $2^{\text {nd }}$ ed. Basil Blackwell, 1991

Markowitz, H.M., D.W. Reid and B. V. Tew. 1994. "The Value of a Blank Check,” The Journal of Portfolio Management, pp. 82-91 Summer.

Muelbroek, Lisa. 2002. Company stock in pension plans: how costly is it? Harvard Business School working paper 02-025.

Pulley, L.M. 1981. "A General Mean-variance Approximation to Expected Utility for Short Holding Periods," Journal of Financial and Quantitative Analysis, 16, pp. 361-73

Pulley, L.M. 1983. "Mean-variance Approximations to Expected Logarithmic Utility," Operations Research, 31 (4), pp. 685-96.

Rousseau, Denise M.; Shperling, Zipi. 2003. "Pieces of the Action: Ownership and the Changing Employment Relationship," Academy of Management Review, 28(4), pp. 553570 . 
Savage, L.J. 1954. The Foundations of Statistics, John Wiley \& Sons. Second revised ed. Dover, New York.

Sharpe, W.F. 1964. "Capital Asset Prices: A Theory of Market Equilibrium Under. Conditions of Risk," Journal of Finance, Vol.19, pp.425-442.

Simaan, Yusif. 1993. "What is the Opportunity Cost of Mean-Variance Investment Strategies?" Management Science 39, (5), pp. 578-587, May

Smith, Adam. 1776. The Wealth of Nations. New York: The Modern Library.

Tobin, J. 1958. "Liquidity Preference as Behavior Towards Risk," The Review of Economic Statistics, No. 67, February, 65-86.

Tversky, Amos and Daniel Kahneman. 1981. "The framing of decisions and the psychology of choice," Science, 211, 453-458.

Tversky, Amos and Daniel Kahneman. 1986. "Rational choice and the framing of decisions," Journal of Business 59(4), Part 2, S251-78.

Tversky, Amos and Daniel Kahneman. 1991. "Loss aversion in riskless choice: a reference dependent model," Quarterly Journal of Economics 106(4), 1039-61 (November). 


\section{Table 1. The Economic Insecurity Score}

$\begin{array}{lll}\text { Score } & \text { Percent } & \text { \# } \\ & & \\ 0 & 0.26 \% & 59 \\ 1 & 2.62 \% & 603 \\ 2 & 7.56 \% & 1,737 \\ 3 & 12.15 \% & 2,792 \\ 4 & 14.54 \% & 3,341 \\ 5 & 16.22 \% & 3,728 \\ 6 & 16.50 \% & 3,792 \\ 7 & 14.13 \% & 3,248 \\ 8 & 9.73 \% & 2,237 \\ 9 & 4.40 \% & 1,010 \\ 10 & 1.88 \% & 433\end{array}$

Mean=5.28; Median=5; s.d. $=2.12 ; n=22,980$ 


\section{Table 2. Economic Insecurity Score and Attitudes, Preferences, and Outcomes For Workers With Any Shared Capitalist Practice}

Note: Each line represents a separate regression, containing coefficient and T-statistic for Economic Insecurity Score in predicting the dependent variable at the left. Controls are noted at bottom.

\section{Attitudes}

Summative attitudes measure (0-20, ordered probit) Important to work in a company that provides stock ownership or stock options to its employees (0-10, ordered probit)

Feel like an owner (1-10, ordered probit)

Ownership important to me (1-10, ordered probit)

How important stock options were in attracting you to work for the company (1-4, ordered probit)

Importance of Employee Stock Purchase Plan in attracting you to work at the company( $0-4$, ordered probit)

How important the ESOP was in attracting you to work for the company (1-4, ordered probit)

Extent to which a cash incentive would increase your motivation to improve the business success of the company (0-4, ordered probit)

Extent to which open market purchases of company stock would increase your motivation to improve the business success of the company (0-4, ordered probit)

Extent to which stock options would increase your motivation to improve the business success of the company (0-4, ordered probit)

Extent to which buying company stock in an Employee Stock Purchase Plan would increase your motivation to improve the business success of the company $(0-4$, ordered probit)

Line Coeff. $\quad$ T-stat. $\mathrm{n} \quad$ R-sq.

$2 \quad-0.062 * * * \quad-11,27 \quad 17,9670.032$

$3-0.125 * * * \quad-22.9017,9540.060$

$4 \quad-0.050 * * * \quad-6.83 \quad 10,4260.032$

$5 \quad-0.034 * * * \quad-3.66 \quad 6,964 \quad 0.021$

$\begin{array}{lllll}6 & -0.063 * * * & -5.77 & 5,210 & 0.025\end{array}$

$\begin{array}{lllll}7 & -0.024 & -1.37 & 1,898 & 0.034\end{array}$

$\begin{array}{lllll}8 & 0.059 * * * & 6.65 & 7,727 & 0.008\end{array}$

$\begin{array}{llll}-0.050 * * * & -5.46 & 6,430 & 0.013\end{array}$

Extent to which an ESOP would increase your motivation to improve the business success of the company (0-4, ordered probit) $\begin{array}{llll}-0.054 * * * & -3.03 & 1,902 & 0.029\end{array}$

Ranking of the following relative to the other incentives in affecting one's motivation to improve the 
business success of the company

(0-3 lowest-highest rank, ordered probit)

cash bonus

$\begin{array}{lllll}13 & 0.036^{* *} & 2.44 & 3,067 & 0.055 \\ 14 & 0.063 * * * & 4.23 & 3,112 & 0.033 \\ 15 & -0.060^{* * *} & -4.12 & 2,908 & 0.031 \\ 16 & -0.038^{* * *} & -2.75 & 3,120 & 0.044\end{array}$

401k company stock match

company-wide profit sharing plan

\section{Preferences}

Summative preferences measure a (0-4, ordered probit)

$17 \quad-0.012$

$-1.58 \quad 10,7070.037$

Preference of variable pay, a 50/50 chance to make $10 \%$ more or $5 \%$ less over fixed pay $(0-1$, probit $)$

18

Preference of variable pay, a 50/50 chance to make $50 \%$ more or $25 \%$ less over fixed pay ( $0-1$, probit)

$-0.076 * * * \quad-4.75 \quad 3,385 \quad 0.122$

Preference for next pay increase as all fixed wages, a mixture of fixed and performance-based, or all performance-based pay (1-3, ordered probit)

Preference of company stock or stock options over cash incentive plan for some of your compensation (1-5, ordered probit)

Preference of variable pay using company stock, profit sharing or stock options over only fixed pay (0-1, probit)

$\%$ less regular pay worker is willing to accept to get a possible performance bonus of $10 \%$ on average of regular pay annually with the risk it could be higher or lower in any given year $(0-100 \%$, OLS)

Ranking of the following as part of a pay raise.

(0-3 lowest-highest rank, ordered probit)

stock options

fixed wage increase

company stock

company-wide profit sharing plan
Would not opt to receive $50 \%$ of ESOP in cash right away or transfer it to another retirement fund versus keeping it entirely in company stock ( $0-1$, probit)

\section{Outcomes}

Summative outcomes rating (0-20, ordered probit)

Not likely to look hard for a job (0-3, ordered probit)
24

25

26

27

$\begin{array}{llll}-0.020 & -1.32 & 1,178 & 0.013 \\ 0.067 * * * & 2.85 & 1,738 & 0.019 \\ -0.072 * * * & -4.00 & 1,691 & 0.015 \\ 0.024 & 1.33 & 1,697 & 0.032\end{array}$

$-19.9317,4690.033$

$-18.3317,9400.036$ 
Feel loyalty to the company (0-3, ordered probit)

See myself working here a long time (0-1, probit)

See current job as part of career $(0-1$, probit)

Will work harder for company (0-4, ordered probit)

Number of days absent (\#, tobit)
$31-0.108^{* * *} \quad-17.4517,7350.060$

$32-0.091^{* * *} \quad-11.18 \quad 17,9530.043$

$33-0.048^{* * *} \quad-6.39 \quad 17,9790.078$

$34-0.063^{* * *} \quad-11.05 \quad 17,9680.040$

$35 \quad 0.171 * * \quad 2.36 \quad 17,6760.018$

It's part of my job to find out how to improve my workgroup or team's performance (0-4, ordered probit)

$36 \quad 0.004$

$-0.11592$

0.078

Days in which I don't put much effort into my job (0-4, ordered probit)

$37-0.011$

$\begin{array}{lll}-1.17 & 6,840 & 0.017\end{array}$

Suggestion meeting frequency ( $0-4$, ordered probit)

38

$-0.054 * * *$

$\begin{array}{lll}-3.48 & 2,224 & 0.033\end{array}$

Offering suggestions frequency $(0-4$, ordered probit $)$

$39 \quad 0.011$

$1.42 \quad 12,643 \quad 0.072$

See the appendix for variable definitions and descriptive statistics.

Regressions include only workers who said they participated in at least one shared capitalist practice (owning company stock, participating in a profit sharing or gain sharing plan, or currently holding or receiving company stock options in the past year). Control variables include age, sex, marital status, children, family size, disability status, education, occupation, full-time status, payment on an hourly rate, hours worked per week, tenure, supervisory status, and log of fixed annual pay.

$* \mathrm{p}<.10 * * \mathrm{p}<.05 * * * \mathrm{p}<.01$ 


\section{Table 3. Bad vs. Good Corporate Culture In the Economic Insecurity Score's Impact on Workplace Outcomes.}

Note: In this table high and low economic insecurity refers respectively to scores above the median, and at or below the median. The empowerment and employee relations scores are similarly divided at the median.

\% Very Likely To Look Hard

For A Job In The Next 12

Months Or Already Looking

High Economic Insecurity/Poor Empowerment/Poor Employee Relations Low Economic Insecurity/Poor Empowerment/Poor Employee Relations

High Economic Insecurity/Good Empowerment/Poor Employee Relations Low Economic Insecurity/Good Empowerment/Poor Employee Relations High Economic Insecurity /Poor Empowerment/Good Employee Relations Low Economic Insecurity/Poor Empowerment/Good Employee Relations

High Economic Insecurity/Good Empowerment/Good Employee Relations Low Economic Insecurity/Good Empowerment/Good Employee Relations
$23.7 \%$

$21.2 \%$

$13.2 \%$

$10.8 \%$

$9.8 \%$

$8.8 \%$

$4.5 \%$

$3.9 \%$ 
Table 4. Empowerment, Employee Relations, and High Performance Work Systems as Predictors of Attitudes, Preferences, and Behavioral Outcomes.

\begin{tabular}{|c|c|c|c|c|c|c|c|c|c|}
\hline Dep. var.: & \multicolumn{3}{|c|}{$\begin{array}{l}\text { Summative attitudes } \\
\text { measure }\end{array}$} & \multicolumn{3}{|c|}{$\begin{array}{l}\text { Summative preferences } \\
\text { measure }\end{array}$} & \multicolumn{3}{|c|}{$\begin{array}{l}\text { Summative outcomes } \\
\text { measure }\end{array}$} \\
\hline $\begin{array}{l}\text { Economic } \\
\text { insecurity }\end{array}$ & $\begin{array}{r}-\mathbf{0 . 1 0 9} \\
(0.005)\end{array}$ & $\begin{array}{r}-\mathbf{0 . 0 5 8} \\
(0.006)\end{array}$ & $\begin{array}{r}-\mathbf{0 . 0 2 9} \\
(0.006)\end{array}$ & $\begin{array}{l}-0.012 \\
(0.007)\end{array}$ & $\begin{array}{l}-0.002 \\
(0.008)\end{array}$ & $\begin{array}{r}-0.004 \\
(0.008)\end{array}$ & $\begin{array}{r}\mathbf{- 0 . 1 0 9} \\
(0.005)\end{array}$ & $\begin{array}{r}-\mathbf{0 . 0 3 3} \\
(0.006)\end{array}$ & $\begin{array}{r}\mathbf{- 0 . 0 3 2} \\
(0.007)\end{array}$ \\
\hline $\begin{array}{l}\text { Lack of } \\
\text { empowerment }\end{array}$ & & $\begin{array}{r}\mathbf{- 0 . 0 9 5} \\
(0.004)\end{array}$ & $\begin{array}{r}-\mathbf{0 . 0 7 2} \\
(0.005)\end{array}$ & & $\begin{array}{l}-\mathbf{0 . 0 2 7} \\
(0.005)\end{array}$ & $\begin{array}{r}\mathbf{- 0 . 0 2 3} \\
(0.006)\end{array}$ & & $\begin{array}{r}-\mathbf{0 . 1 3 2} \\
(0.004)\end{array}$ & $\begin{array}{r}\mathbf{- 0 . 0 9 4} \\
(0.005)\end{array}$ \\
\hline $\begin{array}{l}\text { Poor employee } \\
\text { relations }\end{array}$ & & $\begin{array}{r}\mathbf{- 0 . 0 8 2} \\
(0.002)\end{array}$ & $\begin{array}{r}\mathbf{- 0 . 0 5} \\
(0.003)\end{array}$ & & $\begin{array}{r}-0.003 \\
(0.003)\end{array}$ & $\begin{array}{r}0.005 \\
(0.004)\end{array}$ & & $\begin{array}{r}\mathbf{- 0 . 1 3 9} \\
(0.003)\end{array}$ & $\begin{array}{r}-\mathbf{0 . 1 3 1} \\
(0.004)\end{array}$ \\
\hline HPWS & & & $\begin{array}{r}\mathbf{0 . 0 6 9} \\
(0.004)\end{array}$ & & & $\begin{array}{r}\mathbf{0 . 0 1 8} \\
(0.005)\end{array}$ & & & $\begin{array}{r}\mathbf{0 . 0 7 3} \\
(0.004)\end{array}$ \\
\hline $\mathrm{N}$ & 17922 & 17251 & 11268 & 10707 & 10252 & 9977 & 17469 & 16859 & 10965 \\
\hline R-squared & 0.044 & 0.076 & 0.049 & 0.037 & 0.039 & 0.04 & 0.033 & 0.125 & 0.137 \\
\hline
\end{tabular}

Standard errors in parentheses. Coefficients in bold are significant at $95 \%$ level. Regressions include only workers who said they participated in at least one shared capitalist practice (owning company stock through open market purchases, an Employee Stock Purchase Plan, a 401k plan, the exercise of stock options, or an ESOP, participating in a profit sharing or gain sharing plan, currently holding or receiving company stock options in the past year).

Control variables include age, sex, marital status, children, family size, disability status, education, occupation, full-time status, payment on an hourly rate, hours worked per week, tenure, supervisory status, and log of fixed annual pay. 
Table 5. Values of $\mathrm{V}$ and Sigma for Various Values of $\mathrm{X}$

$\begin{array}{rccc}\mathrm{X} & 1-\mathrm{X} & \mathrm{V} & \text { Sigma } \\ 0.00 & 1.00 & 0.0400 & 0.200 \\ 0.05 & 0.95 & 0.0403 & 0.201 \\ 0.10 & 0.90 & 0.0412 & 0.203 \\ 0.15 & 0.85 & 0.0427 & 0.207 \\ 0.20 & 0.80 & 0.0448 & 0.212 \\ 0.25 & 0.75 & 0.0475 & 0.218 \\ 0.30 & 0.70 & 0.0508 & 0.225 \\ 0.35 & 0.65 & 0.0547 & 0.234 \\ 0.40 & 0.60 & 0.0592 & 0.243 \\ 0.45 & 0.55 & 0.0643 & 0.254 \\ 0.50 & 0.50 & 0.0700 & 0.265 \\ 0.55 & 0.45 & 0.0763 & 0.276 \\ 0.60 & 0.40 & 0.0832 & 0.288 \\ 0.65 & 0.35 & 0.0907 & 0.301 \\ 0.70 & 0.30 & 0.0988 & 0.314 \\ 0.75 & 0.25 & 0.1075 & 0.328 \\ 0.80 & 0.20 & 0.1168 & 0.342 \\ 0.85 & 0.15 & 0.1267 & 0.356 \\ 0.90 & 0.10 & 0.1372 & 0.370 \\ 0.95 & 0.05 & 0.1483 & 0.385 \\ 1.00 & 0.00 & 0.1600 & 0.400\end{array}$




\section{Figure 1:}

Portfolio Standard Deviation

as a function of investment in company stock

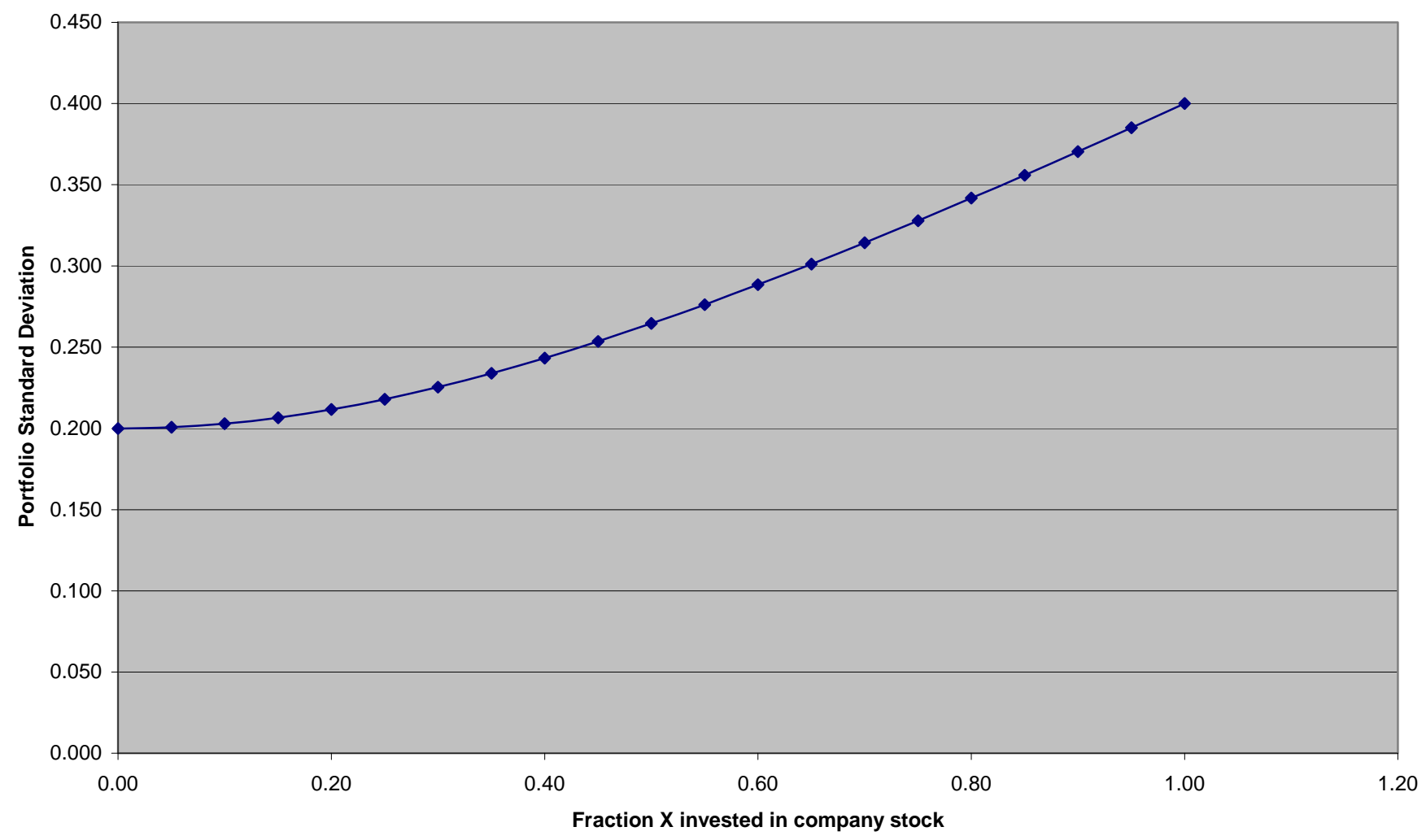

